\title{
Comparison of aqueous humour and serum zinc levels in humans
}

\author{
ALBERT R ANDERSON, PETER R KASTL, AND ZEYNEL A KARCIOGLU \\ From Tulane Medical School, Department of Ophthalmology, New Orleans, Louisiana, USA
}

SUMMARY Zinc concentrations in aqueous humour and serum were determined by means of atomic absorption spectrophotometry in 11 patients with cataract. The zinc content of the aqueous humour was found to be considerably lower than the corresponding serum values. From this finding it is suggested that aqueous humour does not serve as a likely route of delivery of zinc to the cornea.

Recently universal interest in trace elements has stimulated many studies to determine the basic elemental composition of tissues and body fluids. Data on the normal variations of trace element concentrations can be used in determining the pathological significance of alterations found in disease states.

Zinc levels of ocular tissues in man and various other species are well known; their normal variations and pathological concentrations have been elucidated. ${ }^{1-4}$ Although the knowledge of zinc metabolism in the cornea is not extensive, it is assumed that this element is delivered to the cornea primarily by three routes: serum, aqueous humour, and tears, as are many other nutrients. Zinc concentrations in serum and tears have been studied, but very little is known about the role of zinc in the aqueous humour. The present study is designed to determine the aqueous humour zinc concentrations in patients with cataract and to correlate these with serum zinc levels in the same individuals.

\section{Materials and methods}

Eleven cataract patients undergoing surgery were randomly selected and the zinc concentrations in aqueous humour and serum were determined as outlined below. In each case we obtained medical and dietary histories and carried out a physical examination.

Aqueous humour samples $(0 \cdot 1$ to $0 \cdot 3 \mathrm{ml})$ were

Correspondence to Zeynel A Karcioglu, MD, O'Brien Ocular Pathology Laboratory, Tulane University School of Medicine, 1430 Tulane Avenue, New Orleans, LA 70112, USA collected with a tuberculin syringe during the initial stage of cataract surgery. Care was taken to ensure that the wound was free of blood to avoid contamination. A sample of blood was also drawn at the time of surgery. Both specimens were placed in metal-free test tubes and capped with paraffin film. The samples were taken to the laboratory for immediate processing. Zinc levels on all samples were determined in the same laboratory with a Perkin-Elmer flame atomic absorption spectrophotometer, model 703, and HGA 400 graphite furnace. The serum samples were diluted 1:4 serum to double dionised water. The aqueous humour samples were not diluted. For standardisation the Perkin-Elmer Atomic Absorption Manual (January 1982) was used. The detection limits for the flame atomic absorption spectrophotometry were $1 \mathrm{ng} / \mathrm{ml}$ and for the graphite furnace $1 \mathrm{pg} / \mathrm{ml}$. The reproducibility of the assay was $0 \cdot 5 \pm 2 \%$ and $\pm 5 \%( \pm \% \mathrm{SD})$ for the flame atomic absorption spectrophotometry and graphite furnace respectively.

\section{Results}

The study included 11 patients with senile cataracts, five males and six females. Ages ranged from 50 to 73. All patients denied any significant dietary deficiencies in the past. Medical disorders among the group included hypertension, diabetes mellitus, a past history of tuberculosis, chronic pulmonary fibrosis, and sickle cell trait.

Serum zinc levels ranged from 0.705 to $1.06 \mu \mathrm{g} / \mathrm{ml}$, average $0.87 \mu \mathrm{g} / \mathrm{ml} \pm 0.124$ (SD) (Fig. 1). Normal laboratory values for men were $1.2 \pm 0.20 \mu \mathrm{g} / \mathrm{ml}$ and for women $0 \cdot 96 \pm 0 \cdot 13 \mu \mathrm{g} / \mathrm{ml}$. The average values for 


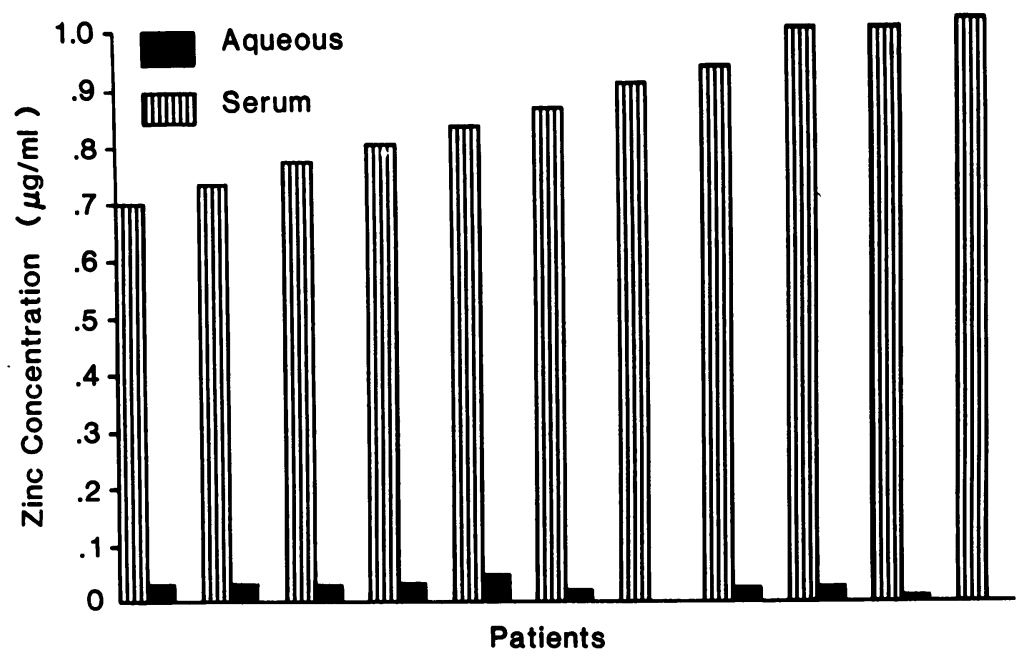

Fig. 1 Approximate comparison of serum and aqueous humour zinc concentrations.

our study group were $0.75 \mu \mathrm{g} / \mathrm{ml}$ for men and 0.96 $\mu \mathrm{g} / \mathrm{ml}$ for women.

Aqueous zinc levels ranged from $0.0001 \mu \mathrm{g} / \mathrm{ml}$ to $0.021 \mu \mathrm{g} / \mathrm{ml}$. The average value was 0.0088 $\mu \mathrm{g} / \mathrm{ml} \pm 0.055$ (SD). The average concentration for males was $0.012 \mu \mathrm{g} / \mathrm{ml}$ and for females $0.005 \mu \mathrm{g} / \mathrm{ml}$. One aqueous sample was too small to be evaluated and one sample was lost in processing.

A Pearson product moment correlation coefficient of serum versus aqueous humour zinc levels was calculated to be $-0 \cdot 27$, indicating no significant correlation between the two.

\section{Discussion}

Zinc is an essential trace element for human growth and is an integral component of many proteins and metalloenzymes. ${ }^{5-7}$ In particular zinc is needed for the maintenance of an intact immune system and for the stabilisation process of nucleic acids, cell membrane, and cellular organelles. ${ }^{7}$

Tauber and Krauss first established the presence of zinc in the eye in $1943 .{ }^{1}$ Later it was shown that the concentration of this metal in ocular tissues is unusually high in comparison with the other parts of the body. The zinc concentration of ocular tissues in descending magnitude are the iris, choroid, sclera, vitreous, lens, cornea, and retina. ${ }^{4}$ The corneal zinc content has been reported as 19.6, 29.8, 41.0 $\mu \mathrm{g} / \mathrm{g}$ in different studies, and, although the details are not well known, this element's role in corneal metabolic functions is well accepted. ${ }^{49}$ Feiler and coworkers have shown that both epithelial and stromal herpes simplex keratitis developed more rapidly in zinc deficient rabbits. ${ }^{10}$ The data from our animal experiments indicate that epithelial and stromal corneal wound healing are markedly delayed in zinc deficient rabbits (Lim J, Karcioglu Z A, unpublished data).

Since corneal wound healing is basically similar to wound healing in skin and other mucosal membranes, it is not surprising to observe delayed healing in zinc deficient states. The effects of zinc on wound healing have been studied well in a number of clinical and experimental trials involving skin and other mucosal tissues, and the studies from a variety of species indicate that zinc is essential for normal wound healing. ${ }^{11} 12$

Zinc has an essential role in a wide spectrum of enzyme systems which affect many metabolic processes, including carbohydrate, protein, and nucleic acid syntheses, which are the basic activities required in tissue repair. ${ }^{67}$ Furthermore, zinc takes part in the stabilisation process of cellular membranes and intracellular organelles. The therapeutic benefit of zinc in wound repair in humans has also been well documented in a number of clinical trials. ${ }^{12-14}$ Hubbard and coworkers tested the use of topical zinc application on wound healing in the corneas of zinc deficient rabbits, but were unable to show any beneficial effects. ${ }^{\text {is }}$ Our studies, on the other hand, performed on zinc deficient experimental animals, clearly indicate a prolonged healing process as measured by the tensile strength of the wound (Lim J, Karcioglu Z A, unpublished data).

Since the role of zinc in the corneal repair process is obvious, it is quite important to determine the route of delivery of this element to cornea. Although our knowledge in this respect is quite limited, it would be reasonable to assume that zinc is delivered to the cornea primarily by three routes: in serum from limbal capillaries, in aqueous humour, and in the tear layer, like other nutrients. Serum zinc in healthy 
individuals is approximately $1 \mu \mathrm{g} / \mathrm{ml}^{{ }^{7}}$ In our laboratory the normal values for men are $1 \cdot 2 \pm 0 \cdot 2$ $\mu \mathrm{g} / \mathrm{ml}$ and for women $0.96 \pm 0.13 \mu \mathrm{g} / \mathrm{ml}( \pm \mathrm{SD})$. In the tear layer the zinc concentration has been determined to be $1.02 \pm 0.31 \mu \mathrm{g} / \mathrm{ml}$ in healthy individuals. ${ }^{16}$ The zinc concentrations in the aqueous humour, on the other hand, have not been studied well. In one previous study the aqueous humour concentration has been calculated to be 0.359 $\mu \mathrm{g} / \mathrm{ml} .{ }^{17}$ In another report, the mean value of zinc in aqueous humour was found to be $1.04 \mu \mathrm{g} / \mathrm{ml}$, but in this study an $x$-ray fluorescein technique was used. The method is old and does not lend itself well to be compared with the previously mentioned report and also with our study. ${ }^{18}$

To the best of our knowledge no comparison of values for aqueous humour and serum has been done previously in simultaneous determinations. The aqueous humour zinc concentrations in our study were extremely small and considerably lower than the corresponding serum values. The average value for the serum zinc concentration was approximately 100 times more than the average value of the aqueous humour zinc. This is not specially surprising, since zinc in serum is bound to proteins, and the total protein level in serum is much higher than the total protein value in the aqueous humour. ${ }^{19}$ Aqueous humour in humans has $0 \cdot 1 \%-0 \cdot 2 \%$ the concentration of plasma protein. ${ }^{20}$ Whatever the reason for the very low zinc levels in aqueous humour, since the average corneal zinc concentration varies between 20 and $40 \mu \mathrm{g} / \mathrm{ml}$, the aqueous does not appear to be a likely route of delivery of zinc to the cornea.

\section{References}

1 Tauber FW, Krauss AC. The role of iron, copper, zinc and manganese in the metabolism of ocular tissues with special reference to the lens. Am J Ophthalmol 1943; 26: 260-6.
2 Leopold IH. Zinc deficiency and visual impairment. Am J Ophthalmol 1978; 85: 871-4.

3 Karcioglu ZA. Zinc in the eye. Surv Ophthalmol 1982; 27: 114-22.

4 Eckhert CD. Elemental concentrations of ocular tissues of various species. Exp Eye Res 1983; 37: 639-47.

5 Underwood EJ. Trace elements in human and animal nutrition. 3rd ed. New York: Academic Press: 1971: 208.

6 Galdez A, Valee BL. Categories of zinc metalloenzymes. In: Sigel $\mathrm{H}$, ed. Zinc and its role in biology and nutrition. New York: Dekker, 1983: 2.

7 Hsu JM. Biochemistry and metabolism of zinc. In: Karcioglu ZA, Sarper RM, eds. Zinc and copper in medicine. Springfield: Thomas, 1980: 597-633.

8 Rosenthal AR, Eckhert CD. Copper and zinc in ophthalmology. In: Karcioglu ZA, Sarper RM, eds. Zinc and copper in medicine. Springfield: Thomas, 1980: 597-633.

9 Leiner M, Leiner G. Der Zinkgehalt in der Augen von Knowchenfischen. Biol Zentralbl 1942; 62: 119-31.

10 Feiler LS, Smolin G, Okumoto M. Herpetic keratitis in zinc deficient rabbits. Invest Ophthalmol Vis Sci 1982; 22: 788-95.

11 Standstead HH, Lanier VC Jr, Shepard GH. Zinc and wound healing: effects of zinc deficiency and zinc supplementation. Am J Clin Nutr 1970; 23: 514-9.

12 Van Rij AM, Pories WJ. Zinc and copper in surgery. In: Karcioglu ZA, Sarper RM, eds. Zinc and copper in medicine. Springfield: Thomas, 1980: 547.

13 Savlov ED, Strain WH, Huegin F. Radio zinc studies in experimental wound healing. J Surg Res 1962; 3: 209-12.

14 Pories WT. Shear EW, Jordan DR. The measurement of human wound healing. Surgery 1966; 59: 821-4.

15 Hubbard GB, Herron BE, Andrews JS. Influence of topical and oral zinc upon corneal wound healing. BrJ Ophthalmol 1969; 53: 407-11.

16 Geordano R, Constantini S, Vernillo I, Rizzica M. Atomic absorption techniques for micro determination of multi elements in all tear film. Atomic Spectroscopy 1983; 4: 157-9.

17 Gerhardt JP, Calme P, Kraeminger E. A propos du zinc de l'humeur aqueuse. Klin Monatsbl Augenheilkd 1980; 176: 652-4.

18 Galin MA, Nano HD, Hall T. Ocular zinc concentration. Invest Ophthalmol Vis Sci 1962; 1: 142-8.

19 Gurd FRN, Goodman DS. Preparation and properties of serum and plasma proteins. 32nd. The interaction on human serum albumin with zinc ions. J Am Chem Soc 1952; 74: 670-5.

20 Maurice DM. Protein dynamics in the eye studied with label proteins. Am J Ophthalmol 1959; 47: 361-7.

Accepted for publication 9 May 1986. 